\title{
Who Takes the Child to the Doctor? Mom, Pretty Much All of the Time
}

\author{
Daly, Moira; Groes, Fane
}

Document Version

Accepted author manuscript

Published in:

Applied Economics Letters

DOI:

10.1080/13504851.2016.1270410

Publication date:

2017

License

Unspecified

Citation for published version (APA):

Daly, M., \& Groes, F. (2017). Who Takes the Child to the Doctor? Mom, Pretty Much All of the Time. Applied Economics Letters, 24(17), 1267-1276. https://doi.org/10.1080/13504851.2016.1270410

Link to publication in CBS Research Portal

\section{General rights}

Copyright and moral rights for the publications made accessible in the public portal are retained by the authors and/or other copyright owners and it is a condition of accessing publications that users recognise and abide by the legal requirements associated with these rights.

Take down policy

If you believe that this document breaches copyright please contact us (research.lib@cbs.dk) providing details, and we will remove access to the work immediately and investigate your claim. 


\title{
Who Takes the Child to the Doctor? Mom, Pretty Much All of the Time
}

\section{Moira Daly and Fane Groes}

\author{
Journal article (Accepted manuscript*)
}

\section{Please cite this article as:}

Daly, M., \& Groes, F. (2017). Who Takes the Child to the Doctor? Mom, Pretty Much All of the Time. Applied Economics Letters, 2417), 1267-1276. 001: 10.1080/13504851.2016.1270410

This is an Accepted Manuscript of an article published by Taylor \& Francis in Applied Economics Letters on २० Dec २०१८, available online:

DOl: http://www.tandfonline.com/10.1080/13504851.2016.1270410

* This version of the article has been accepted for publication and undergone full peer review but has not been through the copyediting, typesetting, pagination and proofreading process, which may lead to differences between this version and the publisher's final version AKA Version of Record.

Uploaded to CBS Research Portal: January २०19 


\title{
Title: Who takes the child to the doctor? Mom, pretty much all of the time. Running Title: Who takes the child to the doctor? Mom, pretty much all of the time.
}

\author{
Moira Daly ${ }^{a}$ \\ Fane Groes $^{b}$ \\ ${ }^{a}$ Copenhagen Business School, Center for Economic Business and Research, Poreclanshaven 16.A Frederiksberg, \\ Denmark, 2000.email: moda.eco@cbs.dk phone+45 262024 88, corresponding author. \\ ${ }^{b}$ Copenhagen Business School, Department of Economics, Poreclanshaven 16.A Frederiksberg, Denmark, 2000
}

\begin{abstract}
We document the degree to which Danish mothers are responsible for handling their children's medical services. Using unique administration data on detailed medical services that were performed on all Danish children from 1992-1995, we find that, on average, more than $90 \%$ of all children's medical services were handled by their mothers rather than their fathers. To our knowledge, this is the first study to use medical register data to quantify domestic time use. As these services are mainly performed during work hours, this finding provides one mechanism by which absenteeism increases as a consequence of motherhood. Furthermore, the economic variables that should affect a household's assignment of a task like taking the child to the doctor are shown to explain very little, suggesting that other factors, such as societal norms, are at play.
\end{abstract}

Keywords: child medical care, child care, household time allocation, family gap

JEL codes: J1, J2, I1, D1

\section{Acknowledgements}

This work was supported by the Danish Social Science Research Council under Grant $300279 .$. We would like to thank Mette Ejrnes and Herdis Steingrimsdottir for their comments.

Manuscript word count, not including title page and acknowledgements but including references: 1999 


\section{INTRODUCTION}

The 'family gap,' the wage difference between women with and without children, persists internationally despite a generally decreasing gender gap. Using U.S. data, Pal and Waldfogel (2014) found that mothers in 2007 were doing no better than mothers in 1977, since the family gap had remained constant at 5-6\%. Even in Denmark, a country with generous family leave, mothers faced a penalty of between $5.1 \%$ and 5.7\% in 2006 (Simonsen \& Skipper 2012).

Interestingly, however, when Simonsen and Skipper redefined their wage variable as earnings over actual hours - contractual or 'normal' hours minus sick days and vacations - the estimated family gap halved and became insignificant; this implies that absenteeism is an important explanation of the family gap in Denmark. The authors conjecture that the higher absenteeism is a consequence of motherhood and that the resulting reduced hours, therefore, are a cost of motherhood. We provide evidence supporting this conjecture using unique administration data on detailed medical services that were performed on all Danish children from 1992 through 1995. To our knowledge, this is the first empirical study of parental time allocation to children's medical services that uses administration data rather than time-use surveys. By using population register data, we avoid the small sample sizes and response selection problems that often occur in self-reported time-use surveys.

Taking a child to the doctor is a domestic task that is not usually traded in the marketplace and is typically done by one parent without the other. The parent who is responsible for taking the child to the doctor must often do so during work hours and without forewarning and is thus a viable explanation for higher absenteeism as a consequence of parenthood. We find that mothers are predominantly the parents who take their children to the doctor. On average, more than $90 \%$ of all children's medical services are handled by mothers.

Why are mothers always responsible for children's medical services? According to Becker (1991), it is because mothers have the comparative advantage. Cooperative bargaining models such as the collective model suggest that this outcome will arise if a mother's bargaining power is low, if she has low opportunity costs, or if she has a strong preference for taking care of the child's medical services (Browning et al. 2014). Finally, obeisance to societal norms may yield this outcome.

Cherchye et al.'s (2012) estimate a collective model with children as a public (domestic) good and find that relative higher female wages reduces her ratio of domestic work to his. ${ }^{1}$ Our results are consistent with the direction of this prediction, yet the magnitudes suggest that other explanations are important, such as those that consider societal norms or strong differences in preferences for child's medical services between parents.

\section{DATA}

We have access to patient level information on doctor services from 1992 onwards. Prior to 1996 , all doctor services received by children under the age of 16 were reported under the

\footnotetext{
${ }^{1}$ Using a subset of the sample for which we have accurate wage information, we verify that the results are similar when using the wage ratio rather than percent of earnings earned by mothers. See online appendix.
} 
identification numbers of the adult who accompanied them and with a child indicator. We focus on children who received a medical service between 1992 and 1995. We restrict our attention to adults with one child and assume that the child being taken to the doctor is their own; this restriction also allows us to identify child-specific characteristics. ${ }^{2}$ Furthermore, we require that the child had no siblings 10 years later. ${ }^{3}$

Using the Danish tax registers, the Integrated Labor Market database (IDA), and the population registers, we append parental earnings information, labor market variables, and demographic information. We consider children whose parents were married or cohabiting and who had positive annual couple earnings in a given year. ${ }^{4}$

Figure 1 displays the fraction of children by age who had at least one doctor service in a year and came from families that met our selection criteria. There are 116,078 children/families in the core estimation sample. The high levels of medical coverage at ages 2 through 5 and 12 are due to check-ups and vaccinations. The low fraction of infants who saw a doctor was driven by children born in November and December.

Figure 1: Fraction of children meeting the selection criteria who had at least one doctor service per year

\section{[INSERT FIGURE 1 HERE]}

Notes: Labels indicate the number of children in the core estimation sample at each age.

Figure 2 provides detail regarding the types of services performed, how often they were performed, and the fraction of these services that were handled by mothers $(\mathrm{fm})$ according to the age of the child pooled over the years 1992-1995. Regardless of the children's ages, mothers handled all services except for those of the on-call doctor more than $80 \%$ of the time. The on-call doctor, used outside of normal working hours, was the service that fathers participated in the most. The younger the child, the more services were required: children less than 2 years old had an average of seven services per year, while children between 2 and 5 had an average of six services per year and children older than 6 had an average of three services per year. That children are less sick with age agrees with the negative correlation between mother's absenteeism and child age that was found by Simonsen and Skipper (2012). Next, we will examine whether mothers' earnings power is correlated with the $\mathrm{fm}$.

Figure 2: Fraction of services handled by mothers by service type and age of child for children meeting selection criteria

\section{[INSERT FIGURE 2 HERE]}

Notes: The first labels on the bars are the mean annual numbers of services in that category followed by the standard deviation in parentheses.

\footnotetext{
${ }^{2}$ See appendix for a discussion of measurement error.

${ }^{3}$ The results do not change if we consider families with one child in the current calendar year, but interpretation becomes more ambiguous as families leave the sample if they have a second child.

${ }^{4}$ We consider children whose parents are either married or cohabiting in given year in order to avoid issues of child custody. Mothers handle even more child services when we also include parents who are not married or cohabiting. See supplemental appendix for figures in this case.
} 
Figure 3 presents the $f m$ according to the child's age and whether or not the mother earned more than $50 \%$ of the couple's income. During the period considered, paid maternity leave was a maximum of 28 weeks. ${ }^{5}$ Figure 3 reflects this: mothers handled virtually all of the doctor-related services for infants (96\%), irrespective of their earnings power. Overall, mothers handled the children's doctor services for more than $90 \%$ of the time on average, regardless of age or whether the mother earns more. The $25^{\text {th }}$ percentile (not shown) is 1 for both types of mothers. Mothers who earned more than fathers accompanied their children less, as the $f m$ of mothers who earned more lies below that of mothers who earned less at all ages save 14. Again, however, there is at most a 2 percentage point reduction here, and it is rarely significant. ${ }^{6}$

Figure 3: Percent of annual services handled by mother by age of child for children meeting the selection criteria

\section{[INSERT FIGURE 3 HERE]}

Notes: $95 \%$ confidence intervals shown.

In order to further investigate this surprisingly high level of motherhood responsibility and its resilience to mothers' earning power, we include a comprehensive list of parental demographic variables, labor market variables, and child attributes in the analysis. For a subsample, we can identify the 2-digit occupations of the parents, the sector in which they work (public or private) as well as the 1-digit industries in which they worked. These variables are available for those parents who worked in the last week of November in the calendar year. Because of potential parental leave, our indicator for working full-time, full-year is not accurate during the years in which the children were born; hence, predictions will be provided for children 2 years and older. Details of all variables and summary statistics are given in the appendix.

\section{METHOD}

We estimate a pooled OLS model in order to generate predictive margins, which we evaluate at the percentage of couple earnings earned by mom. We do not focus on the results of a fixed effect analysis since we are interested constructing these predictive margins, though the results do not change. A fractional response model seems natural, but, as the results are effectively identical, for simplicity we again chose OLS. See the appendix to view both alternatives.

We performed the OLS estimations on the core sample and on the subsample that contained additional labor market variables, constructing predictive margins for four samples: 1) the core estimation sample, 2) the core sample evaluated at covariates that are predicted to decrease $f m$ such that 'mom does less,' 3) the subsample evaluated at covariates such that 'mom does less,' and 4) the subsample evaluated for 'similar couples.'

\section{RESULTS}

\footnotetext{
${ }^{5}$ Publically subsidized child-rearing leaving was also introduced in 1994, see Simonsen and Skipper 2006 for detail

${ }^{6} \mathrm{fm}$ also varies with the number of annual services, but again, never drops below 0.80 , see appendix figure
} 
The results of the pooled OLS estimation are presented in Table II of the appendix. Generally, the partial effects are significant but of small magnitude, are quite similar across estimation samples, and agree with intuition and the literature in that variables which increase mothers' bargaining power lead to decreases in $\mathrm{fm}$. Interestingly, the fraction of services handled by mothers increased throughout the period.

Figure 4 presents the predictive margins. Panel (A) shows the predictive margins for the base sample. Panels (B) and (C) display the predictive margins evaluated when mothers do less: married, self-employed when dad was not, not working in the public sector when dad did, and both working full-time in the same occupation. Panel (D) presents the predictive margins for similar couples who both worked full time in the same occupation and industry, were neither in the public sector nor self-employed, were the same age with the same work experience, and were married.

Figure 4's striking feature is how little $f m$ varies with the household's allocation of a domestic task such as taking the child to the doctor. The sign of the effect of the percent of the couple's total income earned by the mother is as expected, yet its magnitude is quite small. The lowest that $f m$ becomes is 0.85 , and this is when the mother is making all of the couple's income.

Figure 4: Predicted fraction of services handled by mom with children 2 years old or older [INSERT FIGURE 4 HERE]

Notes: Panels (A) through (D) present the predictive margins from OLS estimation.

\section{CONCLUSION}

We show that it is predominantly mothers who take care of children's medical services. As these services are mainly performed during work hours, this finding provides one mechanism by which absenteeism increases as a consequence of motherhood. Standard economic variables that should covary with the household's assignment of tasks that likely do not involve process benefits, such as taking children to the doctor, have only a minimal effect. This suggests that other factors such as societal norms are at play. 


\section{Acknowledgements}

This work was supported by the Danish Social Science Research Council under Grant 300279.. We would like to thank Mette Ejrnes and Herdis Steingrimsdottir for their comments. 


\section{References}

Becker, G.S., 1991. A Treatise on the Family, enl. ed. Cambridge, Mass: Harvard.Browning, M., Chiappori, P.A. and Weiss, Y., 2014. Economics of the Family. Cambridge University Press..

Cherchye, L., De Rock, B. and Vermeulen, F., 2012. Married with children: A collective labor supply model with detailed time use and intrahousehold expenditure information. The American Economic Review, 102(7), pp.3377-3405P

Pal I., and Waldfogel J., 2014 Re-visiting the family gap in pay in the United States. Columbia Population Research Center (CPRC) Working Paper No 14-02 (New York, Columbia University) 2014

Simonsen, M. and Skipper, L., 2012. The family gap in wages: What wombmates reveal. Labour Economics, 19(1), pp.102-112

--------- 2006. The costs of motherhood: an analysis using matching estimators. Journal of Applied Econometrics, 21(7), pp.919-934 


\section{APPENDIX}

The following equation was estimated using pooled OLS on the core estimation sample:

\section{(1)}

\section{[Insert Equation 1 here]}

where $f m_{i t}$ is the fraction of total annual medical service that the mother handled, $a b_{i t}$ is a vector containing dummy variables indicating the age bracket of the child $\left(0-1,2-5\right.$, or 6-10), and pem $_{i t}$ is the percent of couples' labor market earning that are earned by the mother. $X_{i t}$ is a vector containing the self-employment status of each parent and their interaction, marital status, whether the mother was more educated than the father, whether the mom had the same education as the dad, the log of total couple income, the mother's age at birth of child, the age difference between parents, whether each parent worked in the public sector and their interaction, the number of full-time full years of work experience since 1980 for each parent, the sex and age of the child, the annual number of services performed on the child, and year dummies. In addition, a variable based on pension contributions was used to create an indicator for working full time, full year. An indicator for fulltime, full-year employment is included for each parent as well as their interaction. This variable is not accurate during the year in which the child is born. To be conservative, all predictions are calculated for the parents of children who are at least 2 years old.

The subsample contains additional variables from IDA that identify the 2-digit occupation of each parent and the 1-digit industries in which they work. These variables are available for those parents who were working in the last week of November of the calendar year; hence, this subsample represents couples who are more attached to the labor force than the core estimation sample. Estimation (1) is performed on the subsample where $X_{i t}$ is augmented with an indicator of whether 
the parents are in the same occupation and an indicator of whether the parents are in the same industry.

Table AI presents summary statistics for these variables. Note that measurement error may occur if the adult accompanying the child is not a parent or if both parents accompany the child, though we suspect this error to be small. In the former case, a parent with a child under the age of 15 would have to bring another child under the age of 15 . We suspect that, to the degree that this happens, it is random and just adds noise rather than bias. In the latter case, assuming it is the mother who registers, the mother is still responsible for the service; therefore, her measure of percent of visits is still valid.

The results of the pooled OLS estimation are presented in Table AII. Generally, the partial effects are significant but of small magnitude, as all are less than 2 percentage points with the exception of the age bracket of the child. Married, more experienced, self-employed mothers who worked full time along with their husbands fared the best, regardless of which sample was used. If a mother is more educated than a father, she will handle 1 percentage point more services than mothers who are less educated. Mothers of girls will handle 1 percentage point more services than mothers of boys. Interestingly, the fraction of services handled by mothers increased throughout the period, with women handling $1.8 \%$ more of the services in 1995 than in 1992. Fathers helped more as the number of total services increased: each additional service lowered the fraction handled by mothers by $1 \%$. These results are consistent across the estimation samples. From the subsample, we can see that mothers with the same occupation as fathers handled 1.3 percentage point fewer services. If a father works in the public sector but the mother does not, she handles 1.8 percentage points fewer services.

The results of applying a fixed effect estimation are also provided in Table AII. Figure A1 compares the average partial effects of the percent of total couple labor earnings earned by the 
mother from the OLS and FE models. The estimates are similar in size and are not statistically different. Figure A2 displays the average predictions from the fixed effect model in bins corresponding to the percent of couple labor earning earned by mom. Again, these predictions are consistent with Figure 4 in the paper.

Figure A1: APE of percent of couple earning earned by mom, FE vs OLS [Insert Appendix Figure 1 here]

Notes: Bars reflect a $95 \%$ confidence interval.

Figure A2: Average predictions from the fixed effect model [Insert Appendix Figure 2 here]

Figure A3: Distribution of annual child medical services; percent of annual child medical services handled by mother by number of annual child medical 1 services, married or cohabiting

[Insert Appendix Figure 3 here]

Notes: The distribution of annual services for the child are shown on the left axis and the fraction of services handles by mom are shown on the right axis. The value of 15 services captures 15 or more services in a year. 
Table AI: Summary statistics

\begin{tabular}{|c|c|c|}
\hline & (1) & (2) \\
\hline & $\begin{array}{l}\text { Base } \\
\text { Estimation } \\
\text { Sample }\end{array}$ & $\begin{array}{l}\text { Subsample } \\
\text { with Added } \\
\text { Labor Market } \\
\text { Variables }\end{array}$ \\
\hline Fraction of visits handled by Mom & $\begin{array}{l}0.9225 \\
(0.1923)\end{array}$ & $\begin{array}{l}0.9214 \\
(0.1958)\end{array}$ \\
\hline $\begin{array}{l}\text { Percent of couple labor earnings } \\
\text { earned by mother }\end{array}$ & $\begin{array}{l}40.4931 \\
(26.2378)\end{array}$ & $\begin{array}{l}41.8211 \\
(12.5031)\end{array}$ \\
\hline Total number of annual services & $\begin{array}{l}4.6778 \\
(3.1809)\end{array}$ & $\begin{array}{l}4.4472 \\
(3.0883)\end{array}$ \\
\hline Child's age & $\begin{array}{l}6.6951 \\
(4.7865)\end{array}$ & $\begin{array}{l}7.2280 \\
(4.7248)\end{array}$ \\
\hline Indicator: Married & $\begin{array}{l}0.6712 \\
(0.4698)\end{array}$ & $\begin{array}{l}0.7242 \\
(0.4469)\end{array}$ \\
\hline Mom's age at first birth & $\begin{array}{l}28.7337 \\
(4.8242)\end{array}$ & $\begin{array}{l}29.0291 \\
(4.6197)\end{array}$ \\
\hline $\begin{array}{l}\text { Difference in age between Mom } \\
\text { and Dad at first birth }\end{array}$ & $\begin{array}{l}2.2503 \\
(3.9963)\end{array}$ & $\begin{array}{l}2.1247 \\
(3.7793)\end{array}$ \\
\hline Indicator: Male Child & $\begin{array}{l}0.4962 \\
(0.5000)\end{array}$ & $\begin{array}{l}0.4992 \\
(0.5000)\end{array}$ \\
\hline Indicator: more highly-educated & & \\
\hline Mom & $\begin{array}{l}0.2543 \\
(0.4355)\end{array}$ & $\begin{array}{l}0.2647 \\
(0.4412)\end{array}$ \\
\hline Indicator: Mom self-employed & $\begin{array}{l}0.0406 \\
(0.1974)\end{array}$ & $\begin{array}{l}0.0146 \\
(0.1198)\end{array}$ \\
\hline Indicator: Dad self-employed & $\begin{array}{l}0.1273 \\
(0.3333)\end{array}$ & $\begin{array}{l}0.0679 \\
(0.2516)\end{array}$ \\
\hline $\begin{array}{l}\text { Indicator: both parents self- } \\
\text { employed }\end{array}$ & $\begin{array}{l}0.0120 \\
(0.1088)\end{array}$ & $\begin{array}{l}0.0025 \\
(0.0499)\end{array}$ \\
\hline $\begin{array}{l}\text { Indicator: Mom works full year, } \\
\text { full time }\end{array}$ & $\begin{array}{l}0.4442 \\
(0.4969)\end{array}$ & $\begin{array}{l}0.5948 \\
(0.4909)\end{array}$ \\
\hline $\begin{array}{l}\text { Indicator: Dad works full year, full } \\
\text { time }\end{array}$ & $\begin{array}{l}0.6137 \\
(0.4869)\end{array}$ & $\begin{array}{l}0.7475 \\
(0.4344)\end{array}$ \\
\hline $\begin{array}{l}\text { Indicator: both parents work full } \\
\text { year, full time }\end{array}$ & $\begin{array}{l}0.3023 \\
(0.4593)\end{array}$ & $\begin{array}{l}0.4626 \\
(0.4986)\end{array}$ \\
\hline $\begin{array}{l}\text { Mom's full-time years of } \\
\text { experience }\end{array}$ & $\begin{array}{l}9.0822 \\
(4.2203)\end{array}$ & $\begin{array}{l}10.4921 \\
(3.5009)\end{array}$ \\
\hline $\begin{array}{l}\text { Dad's full-time years of } \\
\text { experience }\end{array}$ & $\begin{array}{l}10.7856 \\
(3.9983)\end{array}$ & $\begin{array}{l}12.0142 \\
(3.0481)\end{array}$ \\
\hline $\begin{array}{l}\text { Indicator: Services Performed in } \\
1992\end{array}$ & $\begin{array}{l}0.2563 \\
(0.4366)\end{array}$ & $\begin{array}{l}0.2710 \\
(0.4445)\end{array}$ \\
\hline $\begin{array}{l}\text { Indicator: Services Performed in } \\
1993\end{array}$ & $\begin{array}{l}0.2511 \\
(0.4337)\end{array}$ & $\begin{array}{l}0.2504 \\
(0.4332)\end{array}$ \\
\hline $\begin{array}{l}\text { Indicator: Services Performed in } \\
1994\end{array}$ & $\begin{array}{l}0.2454 \\
(0.4303)\end{array}$ & $\begin{array}{l}0.2460 \\
(0.4307)\end{array}$ \\
\hline $\begin{array}{l}\text { Indicator: Services Performed in } \\
1995\end{array}$ & $\begin{array}{l}0.2472 \\
(0.4314)\end{array}$ & $\begin{array}{l}0.2326 \\
(0.4225)\end{array}$ \\
\hline Log Couple Earned Income & 12.7993 & 13.0993 \\
\hline
\end{tabular}




\begin{tabular}{|c|c|c|}
\hline & $(0.7388)$ & $(0.3046)$ \\
\hline $\begin{array}{l}\text { Indicator: parents ha } \\
\text { occupation }\end{array}$ & & $\begin{array}{l}0.1103 \\
(0.3133)\end{array}$ \\
\hline $\begin{array}{l}\text { Indicator: parents hav } \\
\text { industry }\end{array}$ & & $\begin{array}{l}0.3254 \\
(0.4685)\end{array}$ \\
\hline $\begin{array}{l}\text { Indicator: Mom work } \\
\text { sector }\end{array}$ & & $\begin{array}{l}0.5657 \\
(0.4957)\end{array}$ \\
\hline $\begin{array}{l}\text { Indicator: Dad works } \\
\text { sector }\end{array}$ & & $\begin{array}{l}0.2973 \\
(0.4571)\end{array}$ \\
\hline $\begin{array}{l}\text { Indicator: both parent } \\
\text { public sector }\end{array}$ & & $\begin{array}{l}0.2161 \\
(0.4116)\end{array}$ \\
\hline Observations & 116,078 & 68,630 \\
\hline Number of Children & 43,776 & 29,957 \\
\hline
\end{tabular}

Notes: Mean values are shown with standard deviations (shown in parentheses). 
Table AII: Pooled OLS and Fixed Effect Regressions

Dependent Variable: Fraction of Services Handled by Mom

(1)

(2)

(3)

(4)

\begin{tabular}{|c|c|c|c|c|}
\hline \multirow[b]{2}{*}{ VARIABLES } & \multicolumn{2}{|c|}{$\begin{array}{c}\text { Core Estimation } \\
\text { Sample }\end{array}$} & \multicolumn{2}{|c|}{$\begin{array}{c}\text { Subsample with } \\
\text { Additional LM } \\
\text { Variables }\end{array}$} \\
\hline & OLS & FE & OLS & $\mathrm{FE}$ \\
\hline Indicator: Child <=1 (AB1) & $\begin{array}{c}0.0583 * * * \\
(0.0052)\end{array}$ & $\begin{array}{c}0.0168 * * \\
(0.0084)\end{array}$ & $\begin{array}{c}0.0538 * * \\
(0.0214)\end{array}$ & $\begin{array}{c}0.0399 \\
(0.0308)\end{array}$ \\
\hline Indicator: $2<=$ Child $<=5\left(\mathrm{AB} 2 \_5\right)$ & $\begin{array}{c}0.0342 * * * \\
(0.0055)\end{array}$ & $\begin{array}{l}0.0142 * \\
(0.0078)\end{array}$ & $\begin{array}{c}0.0337 \\
(0.0215)\end{array}$ & $\begin{array}{c}0.0288 \\
(0.0301)\end{array}$ \\
\hline Indicator: $6<=$ Child $<=10\left(\mathrm{AB} 6 \_10\right)$ & $\begin{array}{c}-0.0008 \\
(0.0062)\end{array}$ & $\begin{array}{c}-0.0030 \\
(0.0071)\end{array}$ & $\begin{array}{c}0.0118 \\
(0.0255)\end{array}$ & $\begin{array}{c}0.0330 \\
(0.0328)\end{array}$ \\
\hline
\end{tabular}

Effects of Percent of Couple Earnings Earned by Mom (F) by Age Bracket of Child

\begin{tabular}{|c|c|c|c|c|}
\hline \multicolumn{5}{|l|}{ Child $<=1$} \\
\hline $\mathrm{AB} 1 * \mathrm{~F}$ & $\begin{array}{c}-0.0009 * \\
(0.0005)\end{array}$ & $\begin{array}{c}0.0018 * * * \\
(0.0006)\end{array}$ & $\begin{array}{l}-0.0011 \\
(0.0016)\end{array}$ & $\begin{array}{l}-0.0032 \\
(0.0021)\end{array}$ \\
\hline $\mathrm{AB} 1 * \mathrm{~F}^{2}$ & $\begin{array}{c}0.0000 \\
(0.0000)\end{array}$ & $\begin{array}{c}0.0000 * * * \\
(0.0000)\end{array}$ & $\begin{array}{c}0.0000 \\
(0.0000)\end{array}$ & $\begin{array}{c}0.0001 \\
(0.0000)\end{array}$ \\
\hline $\mathrm{AB} 1 * \mathrm{~F} 3$ & $\begin{array}{l}-0.0000 \\
(0.0000)\end{array}$ & $\begin{array}{c}-0.0000 * * \\
(0.0000)\end{array}$ & $\begin{array}{l}-0.0000 \\
(0.0000)\end{array}$ & $\begin{array}{c}-0.0000^{*} \\
(0.0000)\end{array}$ \\
\hline \multicolumn{5}{|l|}{$2<=$ Child $<=5$} \\
\hline $\mathrm{AB} 2 \_5 * \mathrm{~F}$ & $\begin{array}{c}-0.0010 * * \\
(0.0005)\end{array}$ & $\begin{array}{c}0.0018 * * * \\
(0.0006)\end{array}$ & $\begin{array}{c}-0.0002 \\
(0.0016)\end{array}$ & $\begin{array}{l}-0.0021 \\
(0.0021)\end{array}$ \\
\hline $\mathrm{AB} 2 \_5 * \mathrm{~F}^{2}$ & $\begin{array}{c}0.0000^{* *} \\
(0.0000)\end{array}$ & $\begin{array}{c}0.0000 * * * \\
(0.0000) \\
-\end{array}$ & $\begin{array}{l}-0.0000 \\
(0.0000)\end{array}$ & $\begin{array}{c}0.0001 \\
(0.0000)\end{array}$ \\
\hline $\mathrm{AB} 2 \_5 * \mathrm{~F} 3$ & $\begin{array}{c}-0.0000 * * \\
(0.0000)\end{array}$ & $\begin{array}{c}0.0000 * * * \\
(0.0000)\end{array}$ & $\begin{array}{c}0.0000 \\
(0.0000)\end{array}$ & $\begin{array}{l}-0.0000 \\
(0.0000)\end{array}$ \\
\hline \multicolumn{5}{|l|}{$6<=$ Child $<=10$} \\
\hline AB6_10 * F & $\begin{array}{l}-0.0002 \\
(0.0006)\end{array}$ & $\begin{array}{c}0.0016 * * * \\
(0.0006)\end{array}$ & $\begin{array}{l}-0.0018 \\
(0.0018)\end{array}$ & $\begin{array}{c}-0.0045^{*} \\
(0.0023)\end{array}$ \\
\hline $\mathrm{AB} 6 \_10 * \mathrm{~F}^{2}$ & $\begin{array}{c}0.0000 \\
(0.0000)\end{array}$ & $\begin{array}{c}0.0000 * * \\
(0.0000)\end{array}$ & $\begin{array}{c}0.0000 \\
(0.0000)\end{array}$ & $\begin{array}{c}0.0001 * * \\
(0.0001)\end{array}$ \\
\hline AB6_10* F3 & $\begin{array}{l}-0.0000 \\
(0.0000)\end{array}$ & $\begin{array}{c}-0.0000 * * \\
(0.0000)\end{array}$ & $\begin{array}{l}-0.0000 \\
(0.0000)\end{array}$ & $\begin{array}{c}-0.0000 * * \\
(0.0000)\end{array}$ \\
\hline $\mathrm{F}$ & $\begin{array}{l}0.0008 * \\
(0.0004)\end{array}$ & $\begin{array}{c}0.0014 * * * \\
(0.0005) \\
-\end{array}$ & $\begin{array}{c}0.0009 \\
(0.0013)\end{array}$ & $\begin{array}{c}0.0022 \\
(0.0018)\end{array}$ \\
\hline F squared & $\begin{array}{c}-0.0000 * * \\
(0.0000)\end{array}$ & $\begin{array}{c}0.0000 * * * \\
(0.0000)\end{array}$ & $\begin{array}{l}-0.0000 \\
(0.0000)\end{array}$ & $\begin{array}{l}-0.0001 \\
(0.0000)\end{array}$ \\
\hline \multirow[t]{2}{*}{ F cubed } & $\begin{array}{c}0.0000 * * \\
(0.0000)\end{array}$ & $\begin{array}{c}0.0000 * * * \\
(0.0000)\end{array}$ & $\begin{array}{c}0.0000 \\
(0.0000)\end{array}$ & $\begin{array}{l}0.0000^{*} \\
(0.0000)\end{array}$ \\
\hline & - & - & - & - \\
\hline Total number of services per year & $\begin{array}{c}0.0103 * * * \\
(0.0002) \\
-\end{array}$ & $\begin{array}{c}0.0090 * * * \\
(0.0002)\end{array}$ & $\begin{array}{c}0.0107 * * * \\
(0.0003) \\
-\end{array}$ & $\begin{array}{c}0.0091 * * * \\
(0.0004)\end{array}$ \\
\hline Indicator: Married & $\begin{array}{c}0.0114 * * * \\
(0.0016)\end{array}$ & $\begin{array}{l}-0.0023 \\
(0.0036)\end{array}$ & $\begin{array}{c}0.0125 * * * \\
(0.0020)\end{array}$ & $\begin{array}{c}0.0001 \\
(0.0053)\end{array}$ \\
\hline Mom's age at birth of child & $\begin{array}{l}-0.0002 \\
(0.0002)\end{array}$ & & $\begin{array}{l}0.0005^{*} \\
(0.0003)\end{array}$ & \\
\hline
\end{tabular}


Age difference between Mom and Dad

$$
\text { Child is a girl }
$$

Indicator: Mom has a higher education than Dad

Indicator: Mom and Dad have the same level of education

Mom's full-time years of experience since 1980

Mom's full-time years of experience since 1980 squared

Dad's full-time years of experience since 1980

Dad's full-time years of experience since 1980 squared

Indicator: self-employed Mom, not self-employed Dad

Indicator: self-employed Dad, not self-employed Mom

$$
\text { Indicator: both parents self-employed }
$$

Indicator: Mom worked full time, full year, Dad worked less than full time, full year

Indicator: Dad worked full time, full year, Mom worked less than full time, full year

Indicator: both parents worked full time, full year

$$
\text { Log of couple income }
$$

Indicator: service performed in 1993

Indicator: service performed in 1994

Indicator: service performed in 1995

Indicator: Parents have same 2-digit occupation

Indicator: Parents have same 1-digit industry

Indicator: Mom works in the public sector, Dad does not

Indicator: Dad works in the public sector, Mom does not

Indicator: Both parents work in the public sector

$$
\text { Constant }
$$

$0.0007 * *$
$(0.0002)$
$0.0107 * *$

$(0.0015)$

$0.0109 * * *$

$(0.0020)$

$0.0059 * * *$

(0.0018)

$0.0032 * * *$

(0.0008)

$-0.0001 * *$

(0.0000)

$0.0049 * * *$

(0.0009)

$0.0002 * * *$

(0.0000)

$-0.0105 * *$

(0.0047)

$0.0161 * * *$

(0.0026)

$-0.0100$

(0.0092)

0.0014

(0.0025)

0.0000

(0.0019)

$(0.0022)$

(0.0022)

$0.0103 * * *$

(0.0028)

$0.0081 * * *$

(0.0031)

$0.0059 * * *$

(0.0013)

$0.0099 * * *$

(0.0014)

$0.0150 * * *$

(0.0015)

$0.0181 * * *$

(0.0016)

$-0.0010$

(0.0017)

$0.0053 * *$

(0.0022)

0.0051

(0.0039)

0.0031

(0.0056)

\begin{tabular}{cccc} 
& & $0.0128 * * *$ & 0.0039 \\
& & $(0.0033)$ & $(0.0049)$ \\
& & -0.0003 & 0.0045 \\
& & $(0.0024)$ & $(0.0044)$ \\
& & 0.0035 & 0.0091 \\
& & $(0.0023)$ & $(0.0059)$ \\
& & - & \\
& & $0.0142 * * *$ & 0.0031 \\
& & $(0.0039)$ & $(0.0096)$ \\
$0.9841 * * *$ & $0.9841 * * *$ & $(0.0051)$ & $(0.0107)$ \\
$(0.0173)$ & $(0.0329)$ & $(0.0537)$ & $(0.1240)$ \\
116,078 & 116,078 & 68,630 & 68,630 \\
& 43,776 & & 29,957 \\
\hline
\end{tabular}

$0.0010 * * *$

(0.0003)

$0.0117 * * *$

(0.0019)

$0.0112 * * *$

(0.0026)

0.0048 **

(0.0023)

0.0030 **

(0.0013)

$-0.0001$

(0.0001)

$0.0049 * * * \quad 0.0010$

$(0.0017) \quad(0.0067)$

$0.0002 * * * \quad 0.0002$

(0.0001) (0.0002)

$-0.0015 \quad-0.0204$

$(0.0079) \quad(0.0147)$

$0.0050 \quad-0.0024$

$(0.0039) \quad(0.0083)$

$0.0278 * \quad 0.0311$

$(0.0145) \quad(0.0252)$

$0.0081 * * \quad 0.0081 *$

(0.0034) (0.0042)

$\begin{array}{ll}0.0034 & 0.0029\end{array}$

$(0.0029) \quad(0.0037)$

$0.0101 * * * \quad-0.0066$

(0.0036) (0.0044)

$0.0317 * * * \quad-0.0055$

$(0.0040) \quad(0.0083)$

$0.0087 * * * \quad-0.0067$

$(0.0018) \quad(0.0060)$

$0.0132 * * * \quad-0.0172$

$(0.0020) \quad(0.0115)$

$0.0177 * * * \quad-0.0274$

(0.0024) (0.0172)

$0.0128 * * * \quad 0.0039$

$(0.0033) \quad(0.0049)$

$(0.0024) \quad(0.0044)$

$0.0035 \quad 0.0091$

0.0031

$\begin{array}{ll}-0.0027 & -0.0129\end{array}$

$(0.0051) \quad(0.0107)$

\begin{tabular}{ccccc} 
Constant & $0.9841 * * *$ & $0.9841 * * *$ & $1.3040 * * *$ & $0.9104 * * *$ \\
& $(0.0173)$ & $(0.0329)$ & $(0.0537)$ & $(0.1240)$ \\
Observations & 116,078 & 116,078 & 68,630 & 68,630 \\
Number of couples/children & & 43,776 & 29,957 \\
\hline Robust standard errors in parentheses, *** $\mathrm{p}<0.01, * * \mathrm{p}<0.05, * \mathrm{p}<0.1$
\end{tabular}

\section{Figure Captions}


Figure 1: Fraction of children meeting the selection criteria who had at least one doctor service per year

Notes: Labels indicate the number of children in the core estimation sample at each age.

Figure 2: Fraction of services handled by mothers by service type and age of child for children meeting selection criteria

Notes: The first labels on the bars are the mean annual numbers of services in that category followed by the standard deviation in parentheses.

Figure 3: Percent of annual services handled by mother by age of child for children meeting the selection criteria

Notes: $95 \%$ confidence intervals shown.

Figure 4: Predicted fraction of services handled by mom with children 2 years old or older

Notes: Panels (A) through (D) present the predictive margins from OLS estimation. 


\section{Supplementary materials to be provided on author website}

Figure S1: Distribution of annual doctor services, broken down by age of child, all parents regardless of civil status

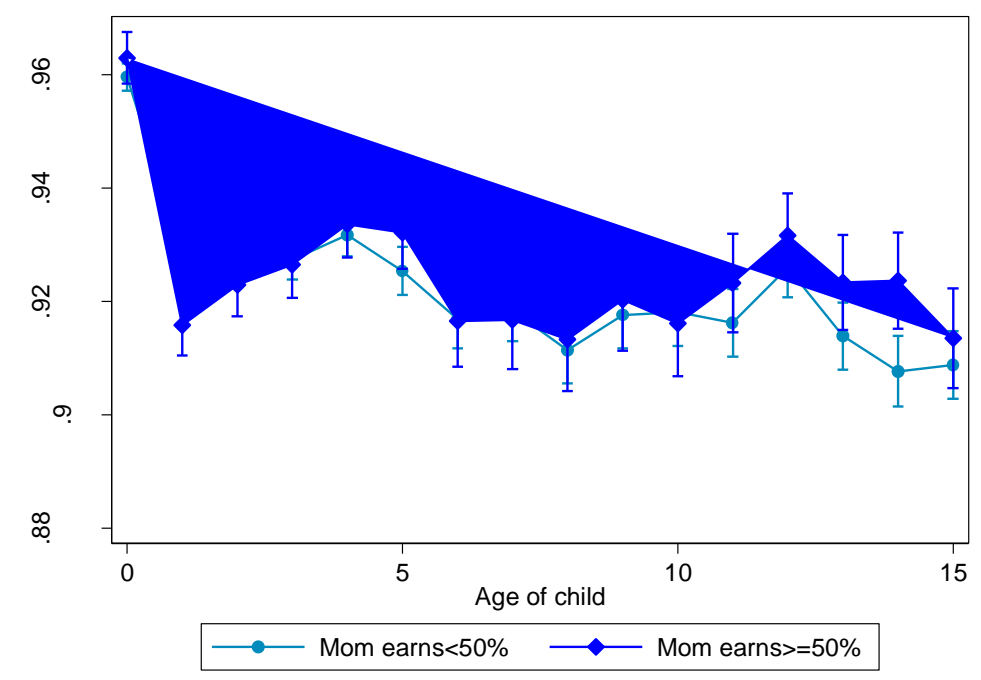


Figure S2: Distribution of annual doctor services, broken down by age of child, all parents regardless of civil status
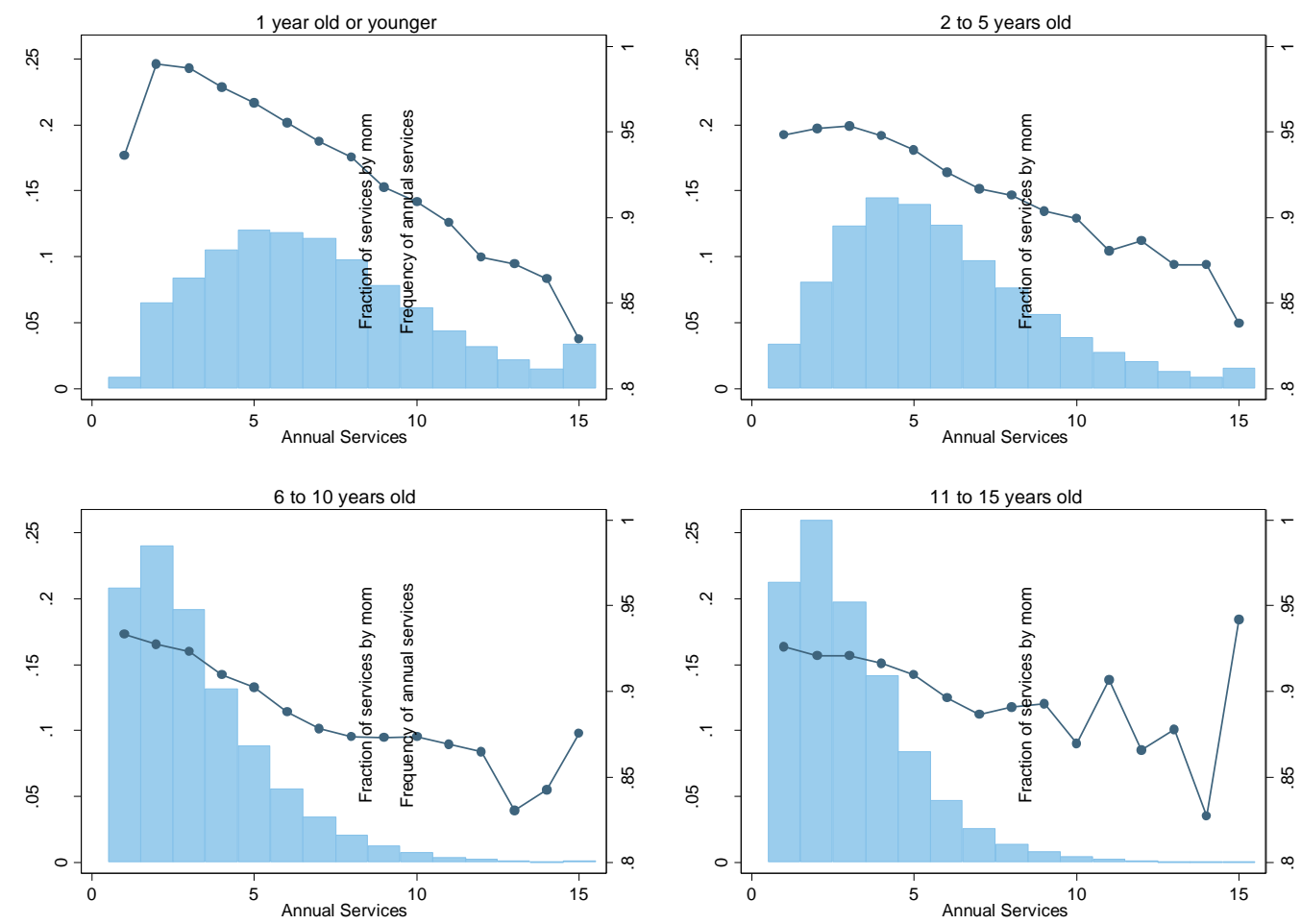
Figure S3 : Predictive margins by age of child
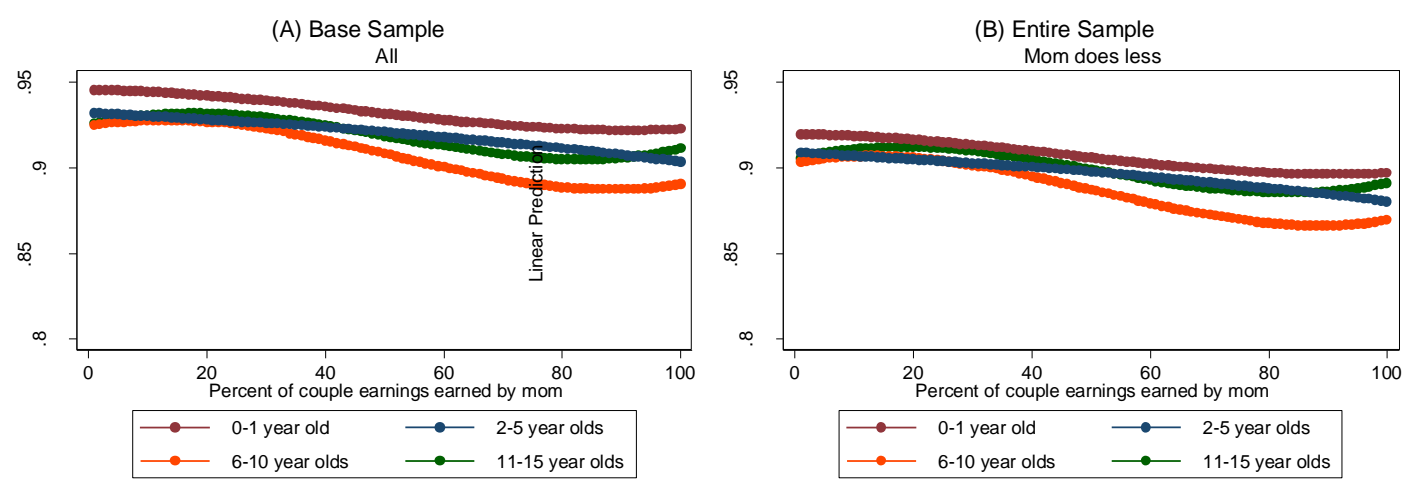

(C) Subsample with additional labor market variables

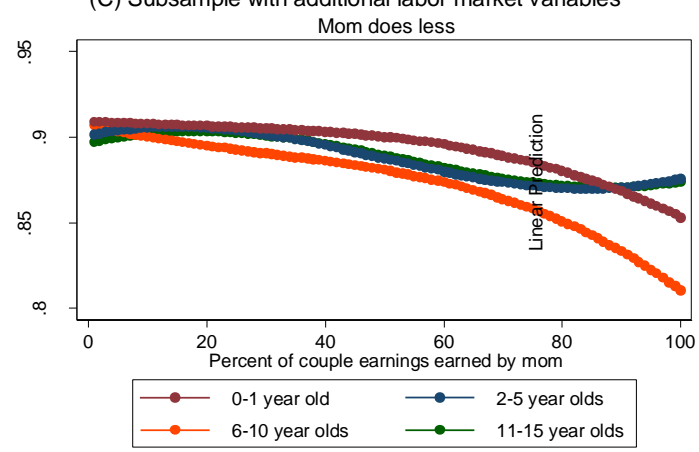

(D) Subsample with additional labor market variables

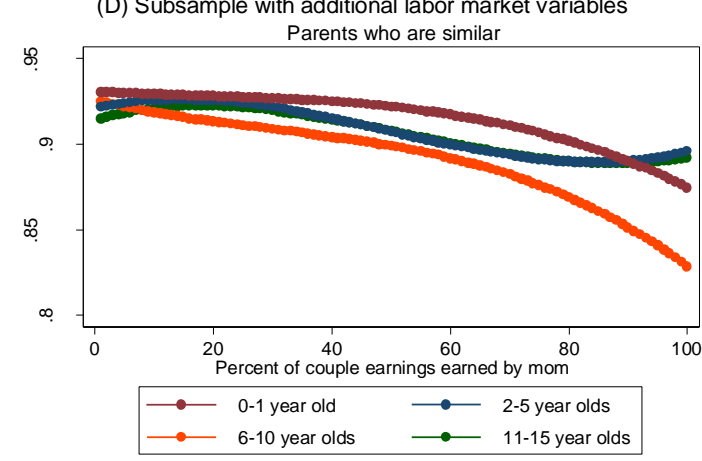


Figure S4: Predicted fraction of visits handled by mom by mom's wage over dad's wage for those with accurate wage information, children 2 years old or older
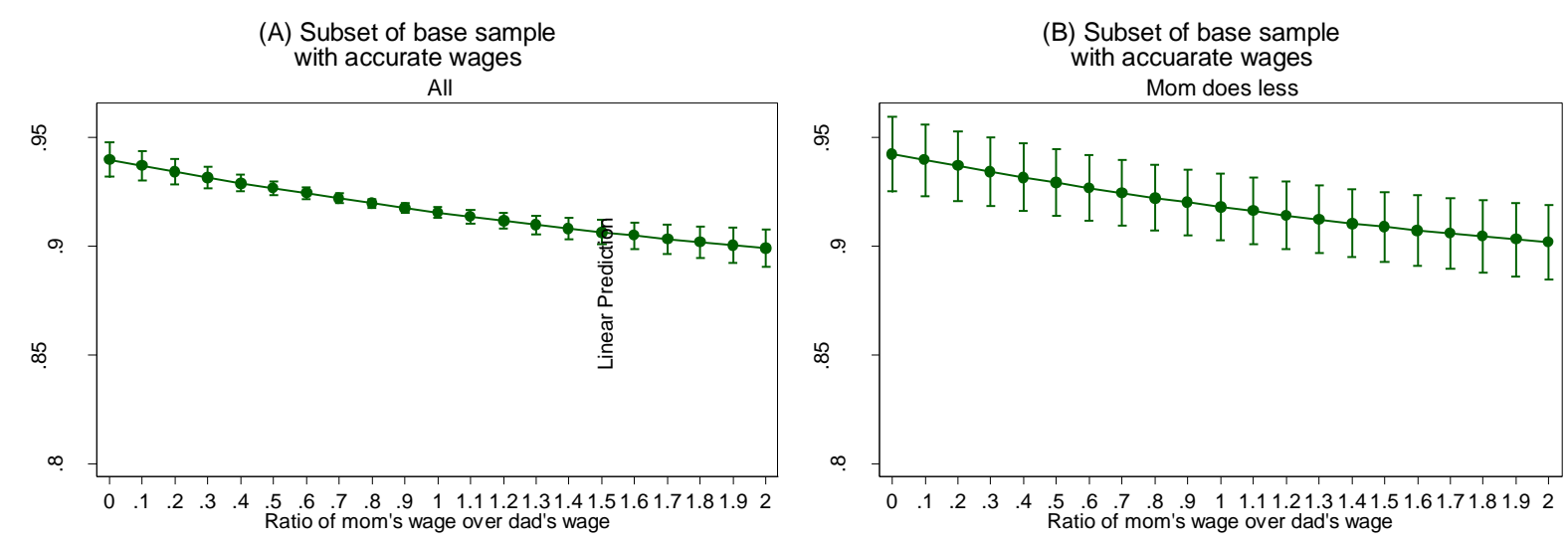

(C) Subsample with additional labor market variables and accurate wages

(D) Subsample with additional labor market variables and accurate wage information
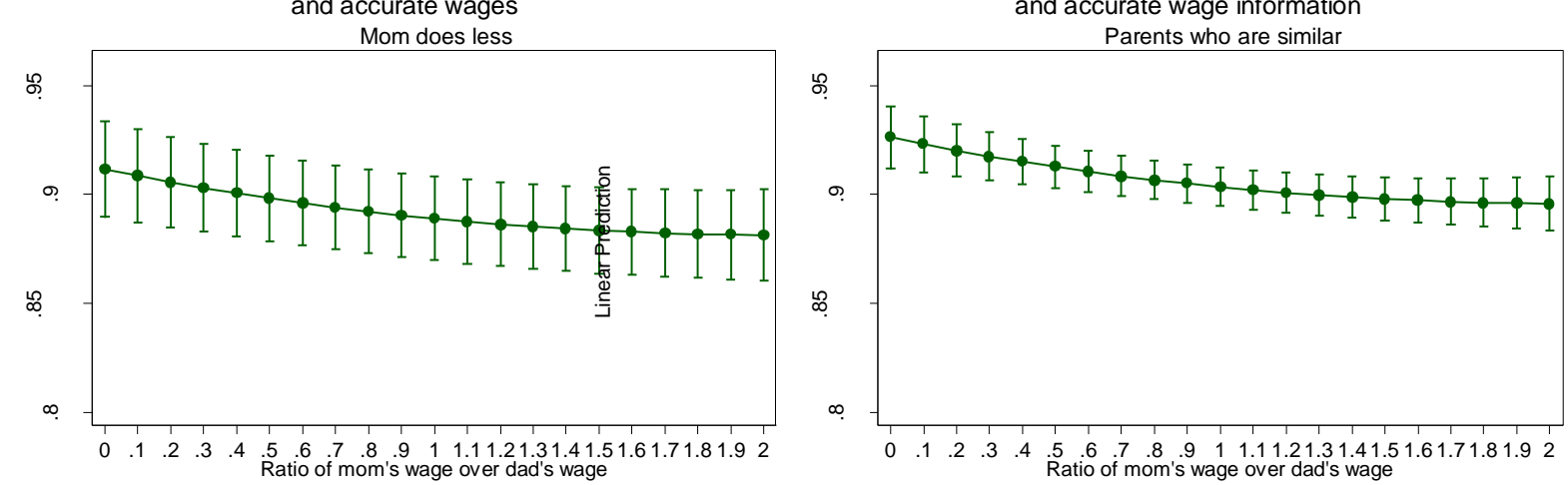
Table S1: APE of Pooled OLS and Fractional Response

\begin{tabular}{|c|c|c|c|c|}
\hline \multirow[b]{3}{*}{ VARIABLES } & (1) & $(2)$ & \multirow{2}{*}{\multicolumn{2}{|c|}{$\begin{array}{l}\text { (3) } \\
\text { Subsample with Additional } \\
\text { LM Variables }\end{array}$}} \\
\hline & \multicolumn{2}{|c|}{ Core Estimation Sample } & & \\
\hline & $O L S$ & $\begin{array}{l}\text { Fractional } \\
\text { Regression }\end{array}$ & $O L S$ & $\begin{array}{l}\text { Fractional } \\
\text { Regression }\end{array}$ \\
\hline \multirow[t]{2}{*}{ Fraction of couple's earnings earned by Mom $(F)$} & $-0.0003 * * *$ & $-0.0003 * * *$ & $-0.0005 * * *$ & $-0.0006 * * *$ \\
\hline & $(0.0000)$ & $(0.0000)$ & $(0.0001)$ & $(0.0001)$ \\
\hline \multirow[t]{2}{*}{ Indicator: Child $<=1(A B 1)$} & $0.0508 * * *$ & $0.0448 * * *$ & $0.0484 * * *$ & $0.0426 * * *$ \\
\hline & $(0.0023)$ & $(0.0015)$ & $(0.0030)$ & $(0.0019)$ \\
\hline \multirow[t]{2}{*}{ Indicator: $2<=$ Child $<=5\left(A B 2 \_5\right)$} & $0.0274 * * *$ & $0.0259 * * *$ & $0.0279 * * *$ & $0.0263 * * *$ \\
\hline & $(0.0022)$ & $(0.0016)$ & $(0.0027)$ & $(0.0021)$ \\
\hline \multirow[t]{2}{*}{ Total number of services in a year } & $-0.0103 * * *$ & $-0.0094 * * *$ & $-0.0107 * * *$ & $-0.0097 * * *$ \\
\hline & $(0.0002)$ & $(0.0002)$ & $(0.0003)$ & $(0.0002)$ \\
\hline \multirow[t]{2}{*}{ Indicator: Married } & $-0.0114 * * *$ & $-0.0119 * * *$ & $-0.0125 * * *$ & $-0.0132 * * *$ \\
\hline & $(0.0016)$ & $(0.0013)$ & $(0.0020)$ & $(0.0017)$ \\
\hline \multirow[t]{2}{*}{ Mother's Age at birth of child } & -0.0002 & -0.0001 & $0.0005 *$ & $0.0005 * * *$ \\
\hline & $(0.0002)$ & $(0.0001)$ & $(0.0003)$ & $(0.0002)$ \\
\hline \multirow[t]{2}{*}{ Age difference between Mom and Dad } & $0.0007 * * *$ & $0.0007 * * *$ & $0.0010^{* * *}$ & $0.0010 * * *$ \\
\hline & $(0.0002)$ & $(0.0002)$ & $(0.0003)$ & $(0.0002)$ \\
\hline \multirow[t]{2}{*}{ Child is a girl } & $0.0107 * * *$ & $0.0107 * * *$ & $0.0117 * * *$ & $0.0116 * * *$ \\
\hline & $(0.0015)$ & $(0.0011)$ & $(0.0019)$ & $(0.0015)$ \\
\hline \multirow[t]{2}{*}{ Indicator: Mom has a higher education than Dad } & $0.0109 * * *$ & $0.0109 * * *$ & $0.0112 * * *$ & $0.0114 * * *$ \\
\hline & $(0.0020)$ & $(0.0015)$ & $(0.0026)$ & $(0.0020)$ \\
\hline \multirow[t]{2}{*}{ Indicator: Mom and Dad have same level of education } & $0.0059 * * *$ & $0.0059 * * *$ & $0.0048 * *$ & $0.0049 * * *$ \\
\hline & $(0.0018)$ & $(0.0013)$ & $(0.0023)$ & $(0.0018)$ \\
\hline \multirow[t]{2}{*}{ Mom's full-time years of experience since 1980} & $0.0014 * * *$ & $0.0013 * * *$ & $0.0014 * * *$ & $0.0013 * * *$ \\
\hline & $(0.0003)$ & $(0.0002)$ & $(0.0004)$ & $(0.0003)$ \\
\hline \multirow[t]{2}{*}{ Dad's full-time years of experience since 1980} & -0.0002 & -0.0002 & -0.0009 & $-0.0008 *$ \\
\hline & $(0.0003)$ & $(0.0003)$ & $(0.0005)$ & $(0.0004)$ \\
\hline \multirow[t]{2}{*}{ Indicator: self-employed Mom } & $-0.0118 * * *$ & $-0.0119 * * *$ & 0.0004 & -0.0002 \\
\hline & $(0.0043)$ & $(0.0035)$ & $(0.0074)$ & $(0.0067)$ \\
\hline \multirow[t]{2}{*}{ Indicator: self-employed Dad } & $0.0157 * * *$ & $0.0152 * * *$ & 0.0054 & $0.0056^{*}$ \\
\hline & $(0.0025)$ & $(0.0018)$ & $(0.0039)$ & $(0.0030)$ \\
\hline \multirow[t]{2}{*}{ Indicator: Mom worked full time for the full year } & $-0.0050 * * *$ & $-0.0046 * * *$ & 0.0006 & 0.0010 \\
\hline & $(0.0018)$ & $(0.0015)$ & $(0.0022)$ & $(0.0019)$ \\
\hline \multirow[t]{2}{*}{ Indicator: Dad worked full time for the full year } & $-0.0046 * * *$ & $-0.0046 * * *$ & -0.0026 & -0.0029 \\
\hline & $(0.0016)$ & $(0.0014)$ & $(0.0021)$ & $(0.0020)$ \\
\hline \multirow[t]{2}{*}{ Log of couple income } & $-0.0059 * * *$ & $-0.0060 * * *$ & $-0.0317 * * *$ & $-0.0317 * * *$ \\
\hline & $(0.0013)$ & $(0.0013)$ & $(0.0040)$ & $(0.0032)$ \\
\hline \multirow[t]{2}{*}{ Indicator: service performed in 1993} & $0.0099 * * *$ & $0.0098 * * *$ & $0.0087 * * *$ & $0.0088 * * *$ \\
\hline & $(0.0014)$ & $(0.0016)$ & $(0.0018)$ & $(0.0022)$ \\
\hline \multirow[t]{2}{*}{ Indicator: service performed in 1994} & $0.0150 * * *$ & $0.0151 * * *$ & $0.0132 * * *$ & $0.0134 * * *$ \\
\hline & $(0.0015)$ & $(0.0017)$ & $(0.0020)$ & $(0.0022)$ \\
\hline \multirow[t]{2}{*}{ Indicator: service performed in 1995} & $0.0181 * * *$ & $0.0179 * * *$ & $0.0177 * * *$ & $0.0177 * * *$ \\
\hline & $(0.0016)$ & $(0.0017)$ & $(0.0024)$ & $(0.0024)$ \\
\hline
\end{tabular}


Indicator: Parents have same 2-digit occupation

Indicator: Parents have same 1-digit industry

Indicator: Mom works in the public sector

Indicator: Dad works in the public sector

$\begin{array}{cc}-0.0128 * * * & -0.0120 * * * \\ (0.0033) & (0.0026) \\ -0.0003 & -0.0004 \\ (0.0024) & (0.0019) \\ 0.0027 & 0.0022 \\ (0.0020) & (0.0016) \\ -0.0157 * * * & -0.0155 * * * \\ (0.0024) & (0.0019)\end{array}$

116,078

116,078

68,630 
